\title{
Long Term Trends of Hydrology, Sediment Yield and Crop Productivity in Andit Tid Watershed Central Highlands of Ethiopia
}

\section{Ayele Desalegn ( $\sim$ ayeledesalegn5@gmail.com )}

Debre Brehan Agricultural Research Center https://orcid.org/0000-0002-3253-9532

\section{Tilahun Getachew}

Debre Brihan Agricultural Research Center

Temesgen Yilma

Debre Brihan Agricultural Research Center

Tilashwork Chanie

Adet Agricultural Research Center

\section{Research}

Keywords: SCRP, Andi tid, PCl, CV, precipitation coefficient, hydrologic, sediment loss

Posted Date: August 4th, 2020

DOI: https://doi.org/10.21203/rs.3.rs-35248/v1

License: (c) (i) This work is licensed under a Creative Commons Attribution 4.0 International License. Read Full License 


\title{
Long term trends of hydrology, sediment yield and crop productivity in Andit Tid watershed central highlands of Ethiopia
}

\author{
Ayele Desalegn ${ }^{1 *}$, Tilahun Getachew ${ }^{1}$, Temesgen Yilma ${ }^{1}$, Tilashwork Chanie ${ }^{2}$ \\ *Corresponding author ayeledesalegn5@gmail.com \\ ${ }^{1}$ Debre Brihan agricultural research center, Debre Brihan, Ethiopia, Po Box 112 \\ ${ }^{2}$ Adet agricultural research center; Adet, Ethiopia
}

\begin{abstract}
Background:

Previously in Ethiopia reliable climatic and hydro-meteorological data are not available and not maintained properly but the long-term database is needed for the assessment and planning of resource dynamics. To minimize the lack of reliable database, the Soil Conservation Research Program (SCRP) established observatory model watersheds since 1981. Andit tid watershed is one of these watersheds established for monitoring the long term trends of climatic, hydrologic, sediment loss and crop production system as a representative site for central high land parts of Ethiopia at 1982. This research paper compiles the analysis of spatial and temporal distribution of the rain fall; trends of run off and sediment loss and their relation and the influence of position of terraces on crop production.
\end{abstract}

Result:

From the rainfall trend analysis result the rainfall of the watershed has insignificant spatial $(P C I=1.07)$ and temporal ( $\mathrm{CV}=16.7 \%)$ variation. The precipitation coefficient $(\%)$ value of the watershed indicates that July and August have big rain with high concentration; September have big rain with moderate concentration and these three months could contribute more than one twelfth of total rainfall amount. The highest runoff and sediment yield were observed in August and July, while sediment concentration was generally high in June. All crops delivered statistically highest yield $(P<0.05)$ immediately above bunds (zone a). 


\section{Conclusion:}

The rainfall spatial and temporal distribution trend analysis results conclude that the watershed is not vulnerable for future drought. The highest sediment concentration occurred in June was because of the reason that the lands are plowed and prepared for crop growth; following this small rainfall can carry much soil and can contribute for high suspended sediment concentration. The highest grain yield obtained from above bunds is because of the trapped and accumulated soil and plant nutrient could contribute for better performance and production of crops. To obtain better crop yield; to minimize sediment loss and improve the stream flow it is better to maintain the existed soil and water conservation structures and apply the new interventions.

Key words: SCRP, Andi tid, PCI, CV, precipitation coefficient, hydrologic, sediment loss

\section{Background}

In most countries reliable climatic and hydro-meteorological data are not available and not maintained properly but the long-term database is needed for the assessment and planning of resource dynamics and its impacts on human life. Data on soil erosion and its controlling factors can be collected in the field or simulated conditions, in the laboratory (Hudson, 1982; Morgan, 1995). For realistic data on soil loss, field measurements are the most reliable because condition varies in both time and space, it is often difficult to determine the causes of erosion or understand the process at work (Hudson, 1982). But in countries like Ethiopia where the agro-climatic and topographic conditions are too diverse, it is difficult and expensive to monitor hydrological and related soil loss data (Tegenu, 2009). It is not possible to measure runoff-soil

loss processes at every vulnerable spot in the country and most physical based models usually have extensive data requirements and it is difficult to build input parameters.

Andit Tid watershed was established in June 1982 as one of seven long term Soil Conservation Research Project (SCRP) sites. The goal of establishing this watershed was stated as to develop and promote ecologically sound, economically viable and socially acceptable conservation measures in Ethiopian highlands'. To achieve this goal long-term monitoring of this model watershed has been conducted. In Andit Tid climate, runoff, sediment loss, crop production and land cover changes have been monitored since June 1982. 
In the watershed different soil and water conservation structures were constructed by different programs since 1994. Even though the function of the constructed structures is not validated, almost a half of the watershed was treated by campaign soil and water conservation structures. To examine and estimate the importance of these conservation structures sediment samples were taken based on the rainfall and runoff events. These long-term collected sediment samples expected to give reliable evidence on the performance of soil and water conservation structures than the erosion empirical models. So in this trend analysis progress we add the analysis of sediment loss with relating other climatic, crop production and hydrologic parameters.

Precipitation directly affects the availability of water resources and is one of the most important climatic factors and hydrological parameters (De Luis et al., 2011). Investigating the temporal variations of precipitation in previous time periods is critical for making reliable predictions of future climate changes.

With mentioned justification the aim of this study were: (1) to analyze the long term data and establish trends of climate (rainfall and temperature), discharge, sediment yield and crop productivity impacts of soil and water conservation practices, and (2) to provide a hydro-sedimentological characterization of the watershed, so that information has been available for longer time series monitoring since 1982 ..

\section{Materials and methods}

\subsection{Description of the study area}

Andit Tid watershed is one of the SCRP sites. It is situated on $39^{\circ} 43^{\prime} \mathrm{E}$ longitudes and $9^{\circ} 48^{\prime} \mathrm{N}$ latitudes (Figure 1) $180 \mathrm{~km}$ northeast of capital city Addis Ababa. The watershed covers a total area of 481 ha, and the altitude of the catchment ranges between 3040 to 3550 m.a.s.l. The mean annual rainfall is $1581 \mathrm{~mm}$, the minimum and maximum temperatures are $7^{\circ} \mathrm{C}$ and $17^{\circ} \mathrm{C}$, respectively. The minimum and maximum average soil temperatures are $8^{\circ} \mathrm{C}$ and $20^{\circ} \mathrm{C}$, respectively. The agro-climatic zone of the watershed is moist humid. Andit Tid has been administered by the Amhara Regional Agricultural Research Institute (ARARI) under the supervision of the Debre Brihan Agricultural Research Center (DBARC). In the study area, there is a huge amount of collected and available data such as discharge, soil loss, climatic, crop productuction and land use/cover data for the last 35 years. 


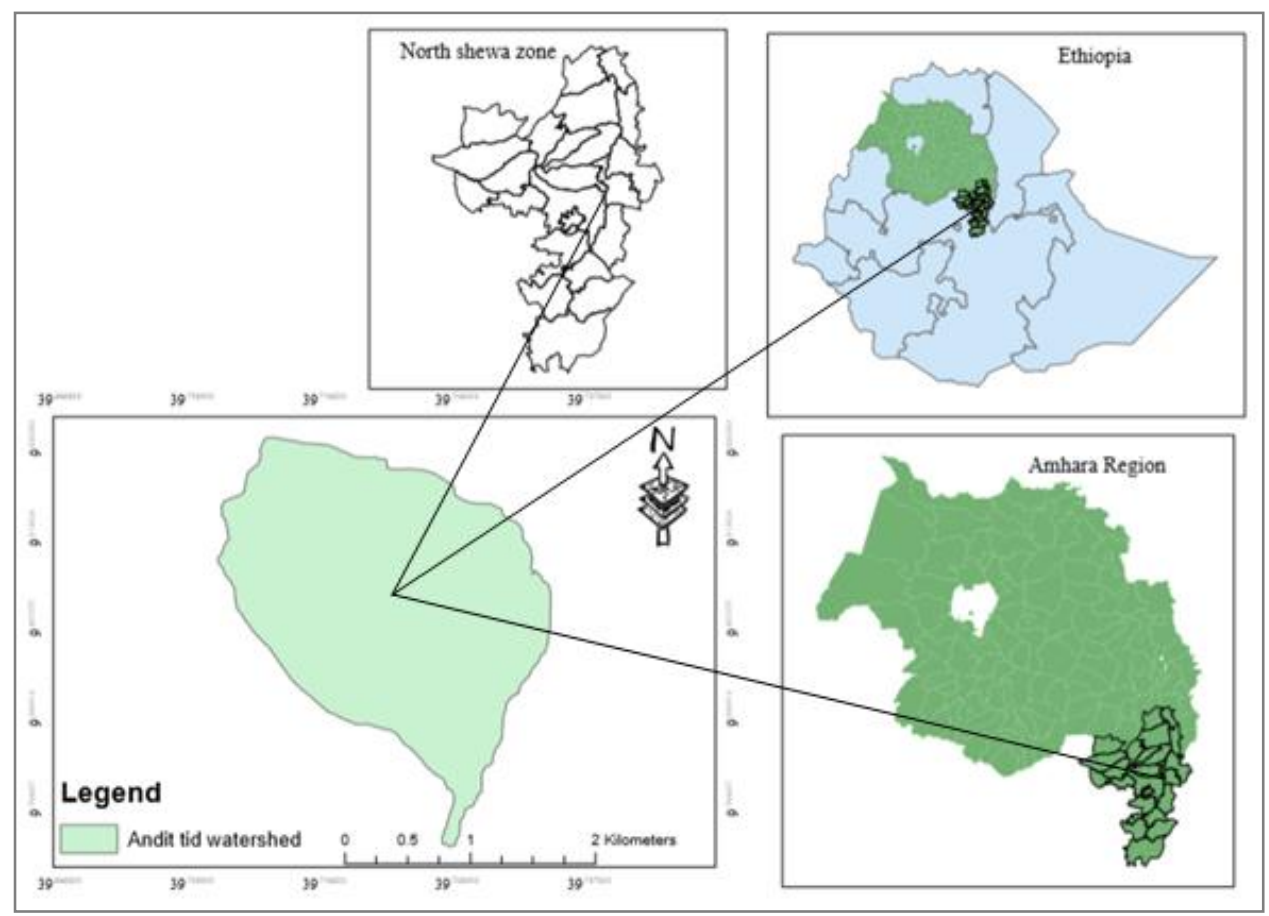

Figure1. The location map of the study area

\subsection{Climatic data collection and analysis}

A-class meteorological instruments were installed near the outlet of the watershed. The rainfall data was recorded using four manual rain gauges, distributed throughout the watershed to collect catchment-scale representative data. From continuous readings of the automatic rain gauge, rainfall characteristics including amount, intensity, and time intervals between storm events were determined.

We used precipitation concentration index (PCI) which is the ratio of square of the rainfall amount of the specific month to the square of the total rainfall to show the distribution of rainfall in the watershed. According to the Oliver (1980), the PCI value of less than $10 \%$ represents a uniform rainfall distribution (i.e. low rainfall concentration); PCI values between 11-15 denote a moderate rainfall concentration; values from 16-20 denote irregular rain fall distribution, and values above $20 \%$ represents the irregularity(i.e. high rainfall concentration) of rainfall distribution (De Luis, 2011).

Precipitation coefficient (PC) was calculated as the ratio between the mean monthly rainfall and one twelfth of the mean annual rainfall. When the PC greater than one, the month is wet month that can contribute more than one twelfth of the mean annual rainfall and dry months contribute less than one twelfth of the mean annual rainfall. A month is rainy if the rainfall coefficient is greater than 0.6. The 
expression "small rains" are used to refer to months with rain fall coefficient of 06-0.9; and the expression "big rains" refer to months with rainfall coefficient of 1 and above. Big rainy months are further classified in to three groups: months with "moderate concentration" (coefficient of 1 to 1.9); months with "high concentration" (coefficient of 2-2.9); and months with "very high concentration" (coefficient of 3 and above) (WLRC, 2015).

The climatic data at the station also include minimum and maximum air temperature, minimum and maximum soil temperature. Air and soil temperature were measured using 1.5 and 0.1 meter above ground thermometers that were installed in the station under shelter respectively.

\subsection{River discharge and sediment data collection}

The river gauge stage was monitored continuously using limuniograph accompanied with manual water level measurements during storm events. Whenever there was runoff events, one-liter grab samples were taken every 10 minutes interval as soon as the water turned brown for sediment measurement. When the water level decreased and the runoff water returned to its original color, sampling rate decreased to 30 minutes intervals and then hour intervals. Together sediment sampling, the river water level was measured manually to determine the total stream flow and to estimate the suspended sediment carried by the flow at that specific time interval. The amount of sediment load within the sample was determined by oven drying the one liter samples then weighing the oven dried soil. Total soil loss for that sampling interval was then calculated by multiplying total water flow per time by the sediment concentration determined from the one liter sample.

The reliability of all collected rainfall, stream flow and suspended sediment load raw data were checked before the analysis. Data events at which the river height was beyond the rating equation were also avoided. Wrongly written starting and ending times for stream flow recordings and sediment samplings were also adjusted.

We used the rating equation developed by Bosshart (1997) to convert stage height to discharge:

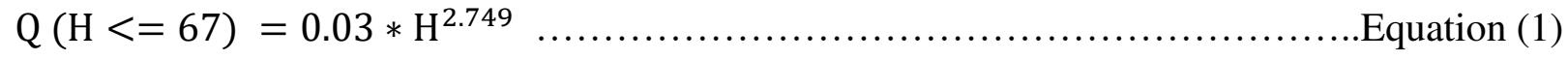

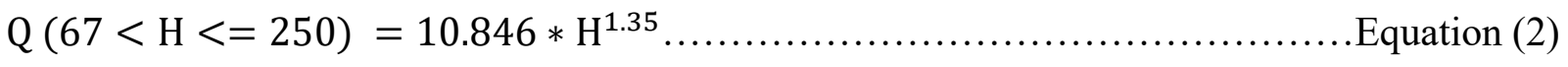

Where $\mathrm{Q}$ is the runoff discharge in $1 / \mathrm{s}$ and $\mathrm{H}$ is the true water level (height of stage) in $\mathrm{cm}$ ??? 
Drainage ratio which is the ratio of runoff to rainfall was calculated to identify when the rainfall and runoff reaches maximum and minimum. Time of concentration is useful in predicting flow rates that would result from hypothetical storms, which are based on statistically derived return_periods through IDF curves (Monjo, R. (2016). The time of concentration $\left(\mathrm{T}_{\mathrm{C}}\right)$ and time of peak discharge ( $\mathrm{T}$ ) were also generated as:

$\mathrm{Tc}=\frac{0.019471 * \mathrm{~L}^{0.77}}{\mathrm{~S}^{0.385}}$ Equation (3)

$\mathrm{S}=\frac{\text { upper stream elevation-Lower stream elevation }}{\mathrm{L}}$ Equation (4)

$\mathrm{TP}=0.6 * \mathrm{~T}$ Equation (5)

Where, $\mathrm{T}_{\mathrm{C}}$ is time of concentration; $\mathrm{L}$ is the length of the largest stream; $\mathrm{S}$ is the slope variation between the upper stream and the lower stream and $\mathrm{T}_{\mathrm{P}}$ is the time of peak discharge.

\subsection{Crop yield data collection}

Catchment harvest data is the representative yield and biomass sample including data on management practices, inputs, soil depth, slope, tillage, precursor crop, and crop type data taken from 35 fixed and 50 non-fixed plots from the farmers' land. In the fixed plot the samples were taken from 'a' (above terrace (zone of deposition)), 'b' (between terrace) and 'c' (below terrace (zone of transportation)) to represent the soil erosion gradient effect. This data was used to show the productivity impacts of SWC applied in the watershed.

\section{Results and discussion}

\subsection{Rainfall characteristics}

The PCI value of the watershed is $1.07 \%$ which means the rainfall in the watershed have uniform distribution (i.e. low rainfall concentration) as shown in Table 1. In fact the distribution of the rainfall can also be verified by the rain fall recorded from four different rain gauges distributed in different location of the watershed. Based on the recorded rainfall from these four rain gauge sites of the watershed there was insignificant variation among the rainfall amount. The precipitation coefficient (\%) value of the watershed indicates that July $(\mathrm{PC}=2.551)$ and August $(\mathrm{PC}=2.395)$ have big rain with high concentration; September 
$(\mathrm{PC}=1.068)$ have big rain with moderate concentration and these three months could contribute more than one twelve of total rainfall amount. The month March, April, May, June and October have small rain with PC values of $0.68,0.82,0.74,0.78$ and o.653 respectively. The month January, February, October and November are dry months as verified from the precipitation coefficient values as mentioned in Table 1.

Table1. The monthly average, annual standard deviation, CV (\%), PC and PCI value of the watershed

\begin{tabular}{|l|c|c|c|c|c|c|c|c|c|c|c|c|c|}
\hline Parameters & Jan & Feb & Mar & Apr & May & Jun & Jul & Aug & Sep & Oct & Nov & Dec & Annual \\
\hline Average & & & & & & & & & & & & & \\
RF(mm) & 60.1 & 54.3 & 93.4 & 112.4 & 101.5 & 107.6 & 351.5 & 330.0 & 147.2 & 90.0 & 67.9 & 65.3 & 1581.0 \\
St. deviation & 36.5 & 32.5 & 54.6 & 65.5 & 52.6 & 49.3 & 82.3 & 78.9 & 64.3 & 67.6 & 45.0 & 44.6 & 264.7 \\
CV (\%) & 60.7 & 59.8 & 58.4 & 58.3 & 51.8 & 45.8 & 23.4 & 23.9 & 43.7 & 75.2 & 66.3 & 68.3 & 16.7 \\
PC & 0.4 & 0.4 & 0.7 & 0.8 & 0.7 & 0.8 & 2.6 & 2.4 & 1.1 & 0.7 & 0.5 & 0.5 & 1.0 \\
PCI (\%) & 0.2 & 0.1 & 0.3 & 0.5 & 0.4 & 0.5 & 4.9 & 4.4 & 0.9 & 0.3 & 0.2 & 0.2 & 1.1 \\
\hline
\end{tabular}

The long-term average annual rainfall based on 20 years of observation (1995-2017) is 1581mm. The maximum and minimum annual rainfall ever received was $2183.6 \mathrm{~mm}$ recorded in 1999 and $1069 \mathrm{~mm}$ which were recorded in 1995. The coefficient of variation for annual rainfall is $16.7 \%$, which means the rainfall amount of each year is fairly scattered around the mean. Derib (2005) states annual rainfall with $\mathrm{CV}>30 \%$ is an indication of high vulnerability to drought. Regardless of the higher monthly rainfall variability; the low variability of total annual rainfall minimizes the risk of drought in the study area. Hurni and Grunder (1986) verified that drought is not a problem in Andit tid because of low variability of annual rainfall. Similar to the previous study; this study also confirms that the watershed will not be vulnerable to drought and dry spell according to the low annual variability of the rainfall. The seasonal rainfall analysis result implied that; since 2008 the rainfall falling at Bulg (February to May) season is less than the long term average rainfall of the Bulg season in most years as shown in Table 2. Holden and Shiferaw (2000) also mentioned that the short rainy seasons have recently become more unreliable. The standardized climatic diagram of Andit Tid (according to Walter, 1964) is characterized by a bimodal rainfall regime with one dryer month (June) between Belg (first, small rainy season) and Kremt (second, main rainy season). Even though the rainfall amount of the Bulg season is smaller than the long term average of the Bulg rain fall; the rain fall regime of the watershed has still bimodal characteristics as mentioned in Table 2. During six months (April, May, June, July. August and September) mean monthly rainfall exceeds $100 \mathrm{~mm}$; with similar result of Walter (1964); which states the four months (May, July, August and September) mean monthly rainfall exceeds $100 \mathrm{~mm}$. 
Table2. The annual average and seasonal rainfall distribution of the watershed from 1995 to 2017 with missing value of 1996 and 1997

\begin{tabular}{|l|c|c|c|c|c|c|}
\hline Year & $\begin{array}{l}\text { Annual } \\
\text { rainfall }\end{array}$ & $\begin{array}{l}\text { Difference } \\
\text { from mean }\end{array}$ & $\begin{array}{l}\text { June-Sept } \\
\text { rainfall }\end{array}$ & $\begin{array}{l}\text { Difference from the } \\
\text { mean June-Sept rainfall }\end{array}$ & $\begin{array}{l}\text { Feb-May } \\
\text { rainfall }\end{array}$ & $\begin{array}{c}\text { Difference from mean } \\
\text { Feb-May rainfall }\end{array}$ \\
\hline 1995 & 1069 & -512.0 & 770.6 & -165.6 & 93.1 & -268.5 \\
1998 & 1863.5 & 282.5 & 1026.2 & 90.0 & 433.9 & 72.3 \\
1999 & 2183.6 & 602.6 & 1231.9 & 295.7 & 454.8 & 93.2 \\
2000 & 1979.7 & 398.7 & 1147.3 & 211.1 & 347.1 & -14.5 \\
2001 & 1650.2 & 69.2 & 960.2 & 24.0 & 403.9 & 42.3 \\
2002 & 1407.7 & -173.3 & 794.8 & -141.4 & 401.3 & 39.7 \\
2003 & 1538.9 & -42.1 & 906.8 & -29.4 & 416.4 & 54.8 \\
2004 & 1699 & 118.0 & 1000.9 & 64.7 & 380.5 & 18.9 \\
2005 & 1574.9 & -6.1 & 911.4 & -24.8 & 401.4 & 39.8 \\
2006 & 1768.8 & 187.8 & 871.6 & -64.6 & 377.9 & 16.3 \\
2007 & 1799.3 & 218.3 & 1079.3 & 143.1 & 487.9 & 126.3 \\
2008 & 1391.5 & -189.5 & 756.8 & -179.4 & 180.6 & -181.0 \\
2009 & 1340.6 & -240.4 & 708.0 & -228.2 & 179.2 & -182.4 \\
2010 & 1655.3 & 74.3 & 1001.5 & 65.3 & 433.2 & 71.6 \\
2011 & 1418.5 & -162.5 & 910.9 & -25.3 & 361.4 & -0.2 \\
2012 & 1364.5 & -216.5 & 900.0 & -36.2 & 310.3 & -51.3 \\
2013 & 1453.1 & -127.9 & 955.4 & 19.2 & 317.8 & -43.8 \\
2014 & 1810.2 & 229.2 & 918.6 & -17.6 & 585.9 & 224.3 \\
2015 & 1193.9 & -387.1 & 681.6 & -254.6 & 216.3 & -145.3 \\
2016 & 1570 & -11.0 & 1149.6 & 213.4 & 359.6 & -2.0 \\
2017 & 1469 & -112.0 & 976.9 & 40.7 & 451.0 & 89.4 \\
\hline Average & 1581.0 & - & 936.2 & -361.6 & - \\
\hline & & & & & &
\end{tabular}

\subsection{Air and soil surface temperature $\left({ }^{\circ} \mathrm{C}\right)$}

The daily minimum air temperature was ranged from $-9{ }^{\circ} \mathrm{C}$ to $23{ }^{\circ} \mathrm{C}$ which was recorded on $22 / 7 / 2017$ and 01/31/2008 respectively. The daily maximum air temperature was ranged from $2{ }^{\circ} \mathrm{C}$ to $26^{\circ} \mathrm{C}$ which was recorded on 11/22/2010 and 08/06/2006 \&01/01/2017 respectively. The daily minimum soil surface temperature was ranged from $-6{ }^{\circ} \mathrm{C}$ to $22{ }^{\circ} \mathrm{C}$ which was recorded on 07 and 09/01/2012 and 03/05/2004 respectively. The daily maximum soil surface temperature was ranged from $1{ }^{\circ} \mathrm{C}$ to $34^{\circ} \mathrm{C}$ which was recorded on 02/01/2014 and 16/06/2010 \& 06/01/2015 respectively. The mean daily minimum and maximum air temperature of the watershed were $7.5^{\circ}$ and $\mathrm{C} 17.6^{\circ} \mathrm{C}$ respectively. The mean daily air temperature of the watershed was $12.6^{\circ} \mathrm{C}$. The mean minimum and maximum soil surface temperature of the watershed were $8^{\circ}$ and $\mathrm{C} 20.5^{\circ} \mathrm{C}$ respectively. The mean soil surface temperature of the watershed was $14.2^{\circ} \mathrm{C}$. 
Table3. The long-term minimum, maximum and mean air and soil surface temperature of the watershed

\begin{tabular}{|c|c|c|c|c|c|c|c|}
\hline Year & $\begin{array}{l}\text { Air } \\
\text { minimum }\left({ }^{\circ} \mathrm{C}\right)\end{array}$ & $\begin{array}{l}\text { Air } \\
\text { maximum }\left({ }^{\circ} \mathrm{C}\right)\end{array}$ & $\begin{array}{l}\text { Mean } \\
\text { temperature } \\
\left({ }^{\circ} \mathrm{C}\right) \\
\end{array}$ & Year & $\begin{array}{l}\text { soil } \\
\text { minimum }\left({ }^{\circ} \mathrm{C}\right)\end{array}$ & $\begin{array}{l}\text { soil } \\
\text { maximum }\left({ }^{\circ} \mathrm{C}\right)\end{array}$ & $\begin{array}{l}\text { Mean } \\
\text { temperature } \\
\left({ }^{\circ} \mathrm{C}\right) \\
\end{array}$ \\
\hline 1995 & 8.0 & 16.2 & 12.1 & 1995 & 7.8 & 20.5 & 14.2 \\
\hline 1996 & 7.7 & 16.0 & 11.8 & 1996 & 7.5 & 19.0 & 13.3 \\
\hline 1997 & 8.4 & 16.3 & 12.3 & 1997 & 6.7 & 19.5 & 13.1 \\
\hline 1998 & 8.5 & 16.9 & 12.7 & 1998 & 7.7 & 20.1 & 13.9 \\
\hline 1999 & 7.4 & 17.0 & 12.2 & 1999 & 6.0 & 20.1 & 13.1 \\
\hline 2000 & 6.1 & 16.6 & 11.4 & 2000 & 7.9 & 21.2 & 14.5 \\
\hline 2001 & 7.5 & 16.9 & 12.2 & 2003 & 8.2 & 19.3 & 13.8 \\
\hline 2002 & 8.3 & 17.5 & 12.9 & 2004 & 7.4 & 20.6 & 14.0 \\
\hline 2003 & 8.1 & 17.3 & 12.7 & 2005 & 7.1 & 22.2 & 14.7 \\
\hline 2004 & 7.7 & 17.9 & 12.8 & 2006 & 7.4 & 21.8 & 14.6 \\
\hline 2005 & 7.7 & 18.6 & 13.2 & 2007 & 7.4 & 20.8 & 14.1 \\
\hline 2006 & 7.3 & 19.0 & 13.2 & 2008 & 7.1 & 21.9 & 14.5 \\
\hline 2007 & 6.2 & 18.7 & 12.5 & 2009 & 7.7 & 23.0 & 15.3 \\
\hline 2008 & 6.9 & 18.9 & 12.9 & 2010 & 8.0 & 21.4 & 14.7 \\
\hline 2009 & 7.7 & 19.2 & 13.5 & 2011 & 8.7 & 19.7 & 14.2 \\
\hline 2010 & 7.5 & 18.4 & 12.9 & 2012 & 7.0 & 18.8 & 12.9 \\
\hline 2011 & 7.5 & 17.4 & 12.4 & 2013 & 8.3 & 18.4 & 13.3 \\
\hline 2012 & 7.1 & 17.2 & 12.1 & 2014 & 8.3 & 18.8 & 13.6 \\
\hline 2013 & 7.6 & 17.4 & 12.5 & 2015 & 10.1 & 21.2 & 15.6 \\
\hline 2014 & 7.5 & 17.0 & 12.3 & 2016 & 10.5 & 20.2 & 15.4 \\
\hline 2015 & 7.6 & 18.2 & 12.9 & 2017 & 10.1 & 21.6 & 15.9 \\
\hline 2016 & 7.1 & 18.1 & 12.6 & $\operatorname{Mean}\left({ }^{\circ} \mathrm{C}\right)$ & 8.0 & 20.5 & 14.2 \\
\hline 2017 & 6.9 & 18.4 & 12.7 & & & & \\
\hline Mean $\left({ }^{\circ} \mathrm{C}\right)$ & 7.5 & 17.6 & 12.6 & & & & \\
\hline
\end{tabular}

The air and soil surface temperature of the watershed did not have a continuous declining or increasing trend. Based on the long term time series air temperature data November and December were the coldest months with average value of $11.5{ }^{\circ} \mathrm{C}$ and $11.4^{\circ} \mathrm{C}$ respectively; whereas May and June are the hottest months with average value of $13.7^{\circ} \mathrm{C}$ and $13.6^{\circ} \mathrm{C}$ respectively. In more than $99 \%$ of the records, daily soil surface temperature was higher than daily air temperature. The difference between air temperatures versus soil surface temperature was greater during the dry season than during the rainy season. With a few exceptions the daily range of soil surface temperature (difference between minimum and maximum temperature) was larger than that of air temperature. Soil surface temperature is more sensitive to seasonal weather variations than air temperature. 


\subsection{Trends of discharge and sediment yield}

Two small rivers, Gudibado and Wadyat, drain the catchment from east to west. Their confluence is approximately $150 \mathrm{~m}$ above the gauging station, which is just upstream of the asphalt bridge crossing of the Hulet Wenz. Both rivers originate from the protected perennial grass lands on a wide plateau located in the upper portion of the watershed where water accumulates and saturates then drains to the two streams. Wadyat River is a perennial river, while Gudibado is mostly seasonal. The stream flow data in the period between 1994 and 2017 shows that the discharge varied between $93.6 \mathrm{~mm}$ (2014) and 1103.7 $\mathrm{mm}$ (1996) with a mean annual discharge of $417.7 \mathrm{~mm}$.

The maximum and minimum annual average sediment loss of Andit tid watershed was 6.45 ton/ha and 0.825 ton/ha which was recorded in 1994 and 2007 respectively. The long term annual average sediment loss of the watershed is 3.4 ton/ha. The rates of river discharge and sediment yield indicate a major impact of mechanical soil conservation measures at catchment level. In some years, though the rainfall amount was decreased, the suspended sediment concentration and sediment loss are increased. This is because of the old soil conservation structures and the need of maintenance of the structure.

The runoff volume was high from 1994 to 2000 but since 2001 it implies decrement and the total annual run off volume was below the mean. In similar condition the sediment loss of the watershed also high from 1994 to 1999 and it starts to decrease from 2000 and continued up to 2007. The decreased quantity of run off and sediment loss since 2000 was expected to be the result of soil and water conservation intervention works applied in the watershed. Whereas the increased trend of sediment loss starting from 2008 was the result of the oldness and destruction of applied soil and water conservation structures due to need of maintenance and other biological strengthen methods. The decreased quantity of runoff volume from 2001 to 2017 may have the relation with other factors (rainfall patterns; soil structure and watershed shape) that did not addressed in this paper. 
Table4. The annual runoff volume, sediment loss and suspended sediment concentration (SSC) of the watershed and the difference from mean of each individual year

\begin{tabular}{|c|c|c|c|c|c|c|c|c|c|c|c|}
\hline Year & $\begin{array}{l}\text { Annual } \\
\text { runoff } \\
\text { (m3) }\end{array}$ & $\begin{array}{l}\text { Difference } \\
\text { from } \\
\text { mean }\end{array}$ & $\begin{array}{l}\text { June-Sept } \\
\text { runoff }\end{array}$ & $\begin{array}{l}\text { Diff from } \\
\text { mean June- } \\
\text { sept runoff }\end{array}$ & $\begin{array}{l}\text { Annual } \\
\text { sedime } \\
\text { nt (ton) }\end{array}$ & $\begin{array}{l}\text { Diff } \\
\text { from } \\
\text { mean }\end{array}$ & $\begin{array}{l}\text { Annual } \\
\text { SSC } \\
(\mathrm{g} / \mathrm{l})\end{array}$ & $\begin{array}{l}\text { June } \\
\text { SSC(g/l) }\end{array}$ & $\begin{array}{l}\text { July } \\
\text { SSC }(g / l)\end{array}$ & $\begin{array}{l}\text { Aug } \\
\text { SSC }(g / l)\end{array}$ & $\begin{array}{l}\text { Sept } \\
\text { SSC (g/l) }\end{array}$ \\
\hline 1994 & 4260765 & 2276675 & 3555128.0 & 2054468.0 & 3064.7 & 1450.6 & 0.7 & 13.7 & 0.6 & 0.7 & 0.0 \\
\hline 1995 & 4721545 & 2737455 & 3469422.2 & 1968762.2 & 2028.3 & 414.2 & 0.4 & 1.8 & 1.3 & 0.2 & 0.0 \\
\hline 1996 & 5242418 & 3258328 & 2805852.8 & 1305192.8 & 2559.2 & 945.1 & 0.5 & 0.2 & 0.6 & 0.5 & 0.6 \\
\hline 1997 & 4071007 & 2086917 & 2275910.2 & 775250.2 & -- & -- & -- & -- & -- & -- & -- \\
\hline 1998 & 2060137 & 76046.75 & 1865094.1 & 364434.1 & 1376.3 & -237.8 & 0.7 & 0.0 & 1.0 & 0.5 & 0.5 \\
\hline 1999 & 2420500 & 436409.7 & 1761390.1 & 260730.1 & 2342.9 & 728.8 & 1.0 & 22.0 & 2.1 & 0.5 & 0.5 \\
\hline 2000 & 2032989 & 48899.1 & 1589601.6 & 88941.6 & 1380.8 & -233.3 & 0.7 & 0.0 & 1.5 & 0.6 & 0.6 \\
\hline 2001 & 1520584 & -463506 & 1411653.0 & -89007.0 & 1466.0 & -148.1 & 1.0 & 0.0 & 2.0 & 0.4 & 0.3 \\
\hline 2002 & 880767 & -1103323 & 856031.3 & -644628.7 & 1021.3 & -592.8 & 1.2 & 0.0 & 4.9 & 1.0 & 0.3 \\
\hline 2003 & 1067722 & -916368 & 906243.9 & -594416.1 & 1368.5 & -245.6 & 1.3 & 7.4 & 2.3 & 0.5 & 0.4 \\
\hline 2004 & 1092495 & -891595 & 924795.1 & -575864.9 & 403.4 & -1210.7 & 0.4 & 0.0 & 0.5 & 0.4 & 0.1 \\
\hline 2005 & 1005153 & -978937 & 980398.0 & -520262.0 & 463.3 & -1150.8 & 0.5 & 2.8 & 0.7 & 0.2 & 0.0 \\
\hline 2006 & 1470352 & -513738 & 1322937.4 & -177722.6 & 1599.2 & -14.9 & 1.1 & 0.0 & 2.5 & 0.6 & 1.0 \\
\hline 2007 & 1147684 & -836406 & 966320.3 & -534339.7 & 392.1 & -1221.9 & 0.3 & 0.5 & 0.7 & 0.2 & 0.0 \\
\hline 2008 & 1155160 & -828930 & 976442.7 & -524217.3 & 1755.1 & 141.0 & 1.5 & 0.0 & 1.3 & 1.8 & 3.8 \\
\hline 2012 & 1448200 & -535890 & 1413896.5 & -86763.5 & 2219.8 & 605.7 & 1.5 & 13.2 & 1.4 & 0.3 & 0.6 \\
\hline 2013 & 1383312 & -600778 & 1026795.4 & -473864.6 & 2140.1 & 526.0 & 1.5 & 0.2 & 3.3 & 1.3 & 1.2 \\
\hline 2014 & 1941020 & -43070.4 & 1039890.4 & -460769.6 & 2958.0 & 1343.9 & 1.5 & 0.0 & 1.2 & 1.1 & 1.2 \\
\hline 2015 & 444779.5 & -1539311 & 337438.1 & -1163221.9 & -- & -- & -- & -- & -- & -- & -- \\
\hline 2016 & 1303781 & -680309 & 1209261.4 & -291398.6 & 582.6 & -1031.5 & 0.4 & 0.0 & 0.4 & 0.2 & 2.2 \\
\hline 2017 & 995513.5 & -988576 & 819362.8 & -681297.2 & 1546.1 & -68.0 & 1.6 & 0.0 & 5.2 & 0.0 & 0.0 \\
\hline Average & 1984090 & 0 & 1500660 & 0 & 1613.7 & 0.0 & 0.9 & 3.3 & 1.8 & 0.6 & 0.7 \\
\hline
\end{tabular}

The long term annual run off of the watershed is $1.984 * 10^{6} \mathrm{~m}^{3}$. From the total volume of the run off $75.6 \%$ was flowed during June to September in the summer season of the watershed and the remaining $24.4 \%$ was flowed during the remaining 8 months including the Bulg season. The long term average sediment loss of the watershed was 1613.7 ton $(3.4$ ton/ha). The long term suspended sediment concentration (SSC) was $0.9 \mathrm{~g} / \mathrm{l}$. The annual suspended sediment yield leaving the catchment varied between 392 ton (2007) and 3064.7 ton (1994), and the annual suspended sediment concentration varied between $0.3 \mathrm{~g} / \mathrm{l}$ (2007) and $1.5 \mathrm{~g} / \mathrm{l}$ (2008, 2012, 2013 and 2014). The suspended sediment concentration (SSC) of June, July, August and September was $3.3 \mathrm{~g} / 1,1.8 \mathrm{~g} / 1,0.6 \mathrm{~g} / 1$ and $0.7 \mathrm{~g} / 1$ respectively; this was expected to have a relation with vulnerability of bare surface (soft plowed land which is prepared for crop growth) to high erosion at the start of the summer season and green coverage and development of high 
cohesion force of the soil after saturation. At mid-June all lands are plowed and prepared for crop growth except some parcels planted at Bulg season; following this small rainfall can carry much soil and can contribute for high suspended sediment concentration at June and relatively in July also. At the midsummer all the farm land and other land use types are covered with green floras and the soil also develop high cohesive force and this leads to decreased suspended sediment concentration at August and September.

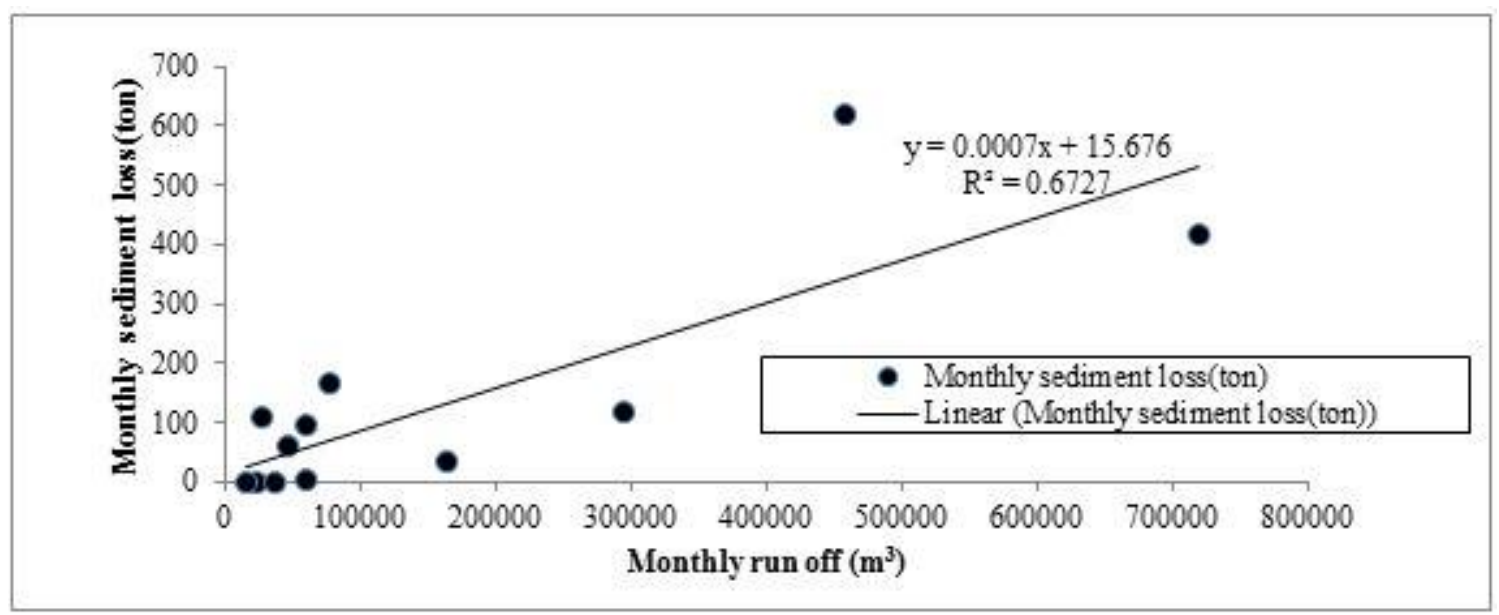

Figure2. The regression chart of monthly sediment loss (ton) and runoff volume $\left(\mathrm{m}^{3}\right)$

The relationship between river discharge and sediment loss in Andit Tid watershed is 67.27\%. The result indicated that as the river discharge increased by $10 \mathrm{~m}^{3}$ the sediment loss will increase by $6.7 \mathrm{~kg}$ of sediment. This result confirms that 67 percent of the agent of sediment loss is runoff and the remaining 33 percent is the result of other factors (edaphic, topographic, and land cover).

\subsection{Time of concentration $\left(T_{C}\right)$}

The time of concentration of the Andit Tid watershed is the result of the length of longest stream and the slope gradient of this stream. With this the length of the stream is $4174 \mathrm{~m}$ and the upper stream elevation and lower stream elevation are $3540 \mathrm{~m}$ and $3020 \mathrm{~m}$ respectively with this the time of concentration of the watershed is 26.61 minute.

\subsection{Trends of crop yield under conserved lands}

Crop yield samples were collected on cultivated land along the existing conservation structures, i.e. within the open area between terraces/bunds. Each cropping season sampling was done permanently on various farmers' cultivated fields in the entire catchment. Three comparable samples within a terrace were taken 
on different locations: one immediately above (zone of deposition), one in between, and one immediately below (zone of transportation) the conservation structures.

Table5. Statistical variation of crop yield over different position of terrace ("a": above, "b": in between terrace and "c": below terraces with $\alpha=0.05$ )

\begin{tabular}{lcccc} 
& \multicolumn{4}{c}{ Average crop yield(kg/ha) } \\
\cline { 2 - 5 } Position & wheat & Barley & Linseed & Horse bean \\
\hline $\mathrm{a}$ & $1245.8 \mathrm{a}$ & 2084.8 & $691.2 \mathrm{a}$ & $927.31 \mathrm{a}$ \\
$\mathrm{b}$ & $1040 \mathrm{~b}$ & 1850.2 & $608.9 \mathrm{ab}$ & $839.7 \mathrm{ab}$ \\
$\mathrm{c}$ & $1020.2 \mathrm{~b}$ & 1651 & $563 \mathrm{~b}$ & $734.5 \mathrm{~b}$ \\
\hline mean & 1102 & 1862.3 & 621 & 833.8 \\
$\operatorname{LSD}(0.05)$ & $* *$ & $\mathrm{~ns}$ & $*$ & $*$ \\
$\mathrm{CV}(\%)$ & 18.54 & 43.07 & 20.97 & 14.34 \\
\hline
\end{tabular}

The result of on-farm yield data in relation to its positions on terraces is shown in Table5. The table shows the impact of conservation structures on the crop productivity. All crops delivered statistically highest yield immediately above bunds and the lowest yield immediately below bunds. This is the result in which the bunds could trap the soil which comes from the upper parts and the accumulated soil expected to have plant nutrients that helps for better performance and production of crops.

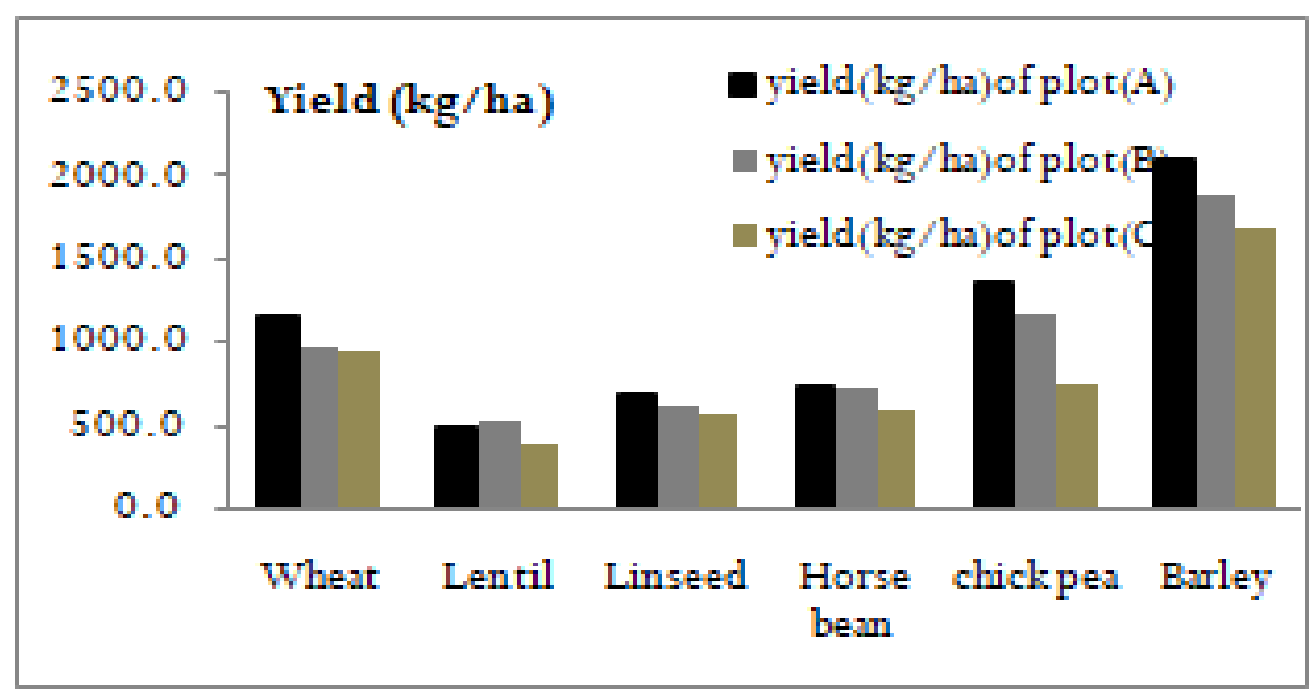

Figure3. The long term mean response of major crops yield for different locations of terraces 
The long term average grain yield result of crops in the study watershed was slightly greater than the grain yield reported by Hurni (2000) from the period (1983-1994). In general, the situation in Andit Tid is difficult for peasants. It is characterized by relatively high population and livestock densities, a high degree of land degradation, low crop yield and production as well as drastically reduced fallow periods (Hurni, 2000). Beside shortage of land, the lack of manure for fertilizer is a main problem for the farmers. Yields are further endangered by hailstorms, frost, pests (i.e. wag, fake) and rodents. The result of on-farm

yield data of commonly growing crops in relation to its positions on terraces is shown in Figure3. Even though the general trend of grain yield in the watershed is low, the graph shows the impact of conservation structures on the yield of crops. Lower yields in the zone below the bunds are expected to be the result of two processes: (1) decreased nutrient level in the soil caused by a loss of topsoil and (2) moisture stress caused by a diminished effective water storage capacity. Nearly for the last 3-4 years the grain yields of all commodity crops are generally declining this is expected to be the result of the diminishing the efficiency of the long term bunds constructed on those plots. The effects of diminishing topsoil in the upper zone of the conservation structure, and the resulting lower plant nutrient capacity immediately below the bunds were not systematically analyzed. Additional information, for example about soil depth and crop type can be found in the primary database.

\section{Conclusion and Recommendation}

This research paper compiles the analysis of temporal distribution of the rain fall, temperature, run off sediment yield and the influence of the position of terraces on crop production. Based on the rainfall analysis the mean annual rainfall of the watershed is $1581 \mathrm{~mm}$ and the distribution has bimodal characteristics which concentrated from March to May and July to September. The PCI value of the watershed is $1.07 \%$ which means the rainfall in the watershed have uniform spatial distribution. From the rainfall trend analysis result the rainfall of the watershed has insignificant variation $(\mathrm{CV} \%=16.7)$ which is an indicator for less vulnerability to drought. The precipitation coefficient (\%) value of the watershed indicates that July $(\mathrm{PC}=2.551)$ and August $(\mathrm{PC}=2.395)$ have big rain with high concentration; September $(\mathrm{PC}=1.068)$ have big rain with moderate concentration and these three months could contribute more than one twelve of total rainfall amount and January, February, October and November are dry months. The long term average runoff and sediment loss of the watershed is $417.7 \mathrm{~mm}$ and 1613.7 ton respectively. There was the decreased quantity of run off and sediment loss since 2000; it was expected to be the result of soil and water conservation intervention works applied in the watershed; whereas the increased trend of 
sediment loss starting from 2008 was the result of the oldness and destruction of applied soil and water conservation structures due to need of maintenance and other biological strengthen methods. The average soil surface and atmospheric temperature of the watershed is $14.2^{\circ} \mathrm{C}$ and $12.6^{\circ} \mathrm{C}$. The result of on-farm yield data shows the impact of conservation structures on the crop productivity. All crops delivered statistically highest yield immediately above bunds and the lowest yield immediately below bunds. This is the result in which the bunds could trap the soil which comes from the upper parts and the accumulated soil expected to have plant nutrients that helps for better performance and crop production.

\section{Ethics approval and consent to participate}

I agree with the ethics of the journal and I consent to participate in the publication process of this journal.

\section{Consent of publication}

Not applicable

\section{Availability of data and materials}

The data and materials used in this manuscript are found with the hand of corresponding author.

\section{Competing of interests}

The authors have no competing of interest.

\section{Funding}

There is no funding options that could I got for publication.

\section{Authors' contributions}

Ayele Desalegn participates in initiating the proposal; encoding the data; organizing and monitoring the data; analysis and interpretation of the data and writing the manuscript. Tilahun Getachew and Temesgen Yilma participate in data encoding and data organization. Tilashwork Chanie participates in initiating the proposal; encoding the data and revising the draft manuscript. 


\section{Acknowledgment}

I acknowledge the Amhara Regional Agricultural Research Institute (ARARI) and Water and Land Resource Center (WLRC) for their financial support during the whole life of this research. I duly thank all the data collectors and guards of Andit tid watershed specifically Mr. Amara Belachew; Mr. Zewdie Assefa and Mr. Solomon Alemu.

\section{Reference}

Allan, R.P. and Soden, B.J. (2008) Atmospheric warming and the amplification of precipitation extremes. Science, 321(5895), 1481-1484.

Bono, R., Seiler, W. 1984. Soil map of the Andit Tid research area, Soil Conservation Research Programme, CDE, Berne, Switzerland

Bosshart, U. 1997. Photo Monitoring University of Berne, Switzerland: Soil Conservation Research Programme.

De Luis, M.et al 2011. Precipitation concentration change in Spain 1946-2005. Nat Hazards Earth Syst. Sci 11:1259-1265

Derib, S.D., 2005. Rainfall-Runoff Processes at a Hill-slope Watershed: Case of Simple Models Evaluation at Kori-Sheleko Catchments of Wollo, Ethiopia. MSc. Thesis

Desta, L., Kassie, M., Benin, S., and Pender, J.: Land degradation and strategies for sustainable development in the Ethiopian highlands, Amhara Region, Socio-economics and Policy Research Working Paper 32, International Livestock Research Institute, Nairobi, Kenya, 2000.

Gete Z., 2014. Hydro climatic data collection and synthesis of Anjeni watershed, Report. Water and land Resource center, Ethiopia

Grunder, M.: Soil conservation research in Ethiopia, Mt. Res. Dev., 8, 145-151, 1988.

Gu, X.H., Zhang, Q., Singh, V.P. and Shi, P.J. (2017) Changes in magnitude and frequency of heavy precipitation across China and its potential links to summer temperature. Journal of Hydrology, $547,718-731$. 
Herweg, K. 1996. Field Manual for Assessment of Current Erosion Damage, University of Berne, Switzerland: Soil Conservation Research Programme.

Herweg, K. and Ludi, E.: The performance of selected soil and water conservation measures- case studies from Ethiopia and Eritrea, Catena, 36, 99-114, 1999.

Holden, S., and Shiferaw, B., 2000, Development paths and policies for Sustainable Land Management in Andit Tid, North Shewa: An Exploration. In: Jabbar, M. A., Pender, J., and Ehui, S., 2000. Policies for Sustainable Land Management in the Highlands of Ethiopia: Summary of Papers and Proceedings of a Workshop held at the International Livestock Research Institute, Addis Ababa, Ethiopia, May 22-23, 2000

Hudson N., 1982. Soil Conservation. B.T. Batsford Ltd. London.324p.

Hurni, H., and Gurdner, M., 1986. Fourth progress report (year 1984), Soil Conservation Research Project, Vol. 5. Addis ababa, Ethiopia

Hurni, H.: Degradation and conservation of the resources in the Ethiopian highlands, Mt. Res. Dev., 8, $123-130,1988$.

Hurni, H., 2000. Area of Andit Tid, Shewa, Ethiopia: Long-term Monitoring of the Agricultural Environment 1982 - 1994, Soil Conservation Research Programme, CDE, Berne, Switzerland.

Hurni, H., Kebede, T., and Gete, Z.: The implications of changes in population, land use, and land management for surface runoff in the upper Nile basin area of Ethiopia, Mt. Res. Dev., 25, 147154, 2005.

Monjo, R. (2016). "Measure of rainfall time structure using the dimensionless n-index". Climate Research. 67: 71-86. doi: $10.3354 /$ cr01359. (pdf)

Morgan R., 1995. Soil Erosion and Conservation. Second Edition. Longman Group UK Ltd., Essex, England. 198p.

Nyssen, J., Poesen, J., Moeyersons, J., Haile, M., and Deckers, J.: Dynamics of soil erosion rates and controlling factors in the northern Ethiopian highlands - towards a sediment budget, Earth Surf. Proc. Land., 33, 695-711, 2008. 
Oliver, J.E. (1980) Monthly precipitation distribution: a comparative index. Professional Geographer, 32, 300-309.

Oliver, J.E.1990. Monthly precipitation distribution: a comparative index, prof. Geogr., 32, 300-309,1980

Tegenu Ashagre. 2009. MODELING RAINFALL, RUNOFF AND SOIL LOSS RELATIONSHIPS IN THE NORTHEASTERN HIGHLANDS OF ETHIOPIA, ANDIT TID WATERSHED, A Thesis Presented to the Faculty of the Graduate School of Cornell University in Partial Fulfillment of the Requirements for the Degree of Master of Professional Studies

Tena Alamirew, Daniel Berhanu, Hans Hurni, and Gete Zeleke 2018. 'Long term agro-climatic and hydro-sediment observatory report: The case of Maybar micro-watershed, Awash River Basin, North-eastern Ethiopia'. WLRC Research Report II, Addis Ababa University,

Vanmaercke, M., Zenebe, A., Poesen, J., Nyssen, J., Vertstraeten,G., and Deckers, J.: Sediment dynamics and the role of flash floods in sediment export from medium-sized catchments: a case study from the semi-arid tropical highlands in northern Ethiopia, J. Soil. Sediment., 10, 611-627, 2010.

Water and Land Resource centers (WLRC), 2015: long term agro climatic and hydro-sedimentological observatory report: the case of Anjeni micro-watershed: WLRC research report 1. Addis Ababa, Ethiopia.

Xiao, M.Z., Zhang, Q. and Singh, V.P. (2017) Spatiotemporal variations of extreme precipitation regimes during 1961-2010 and possible teleconnections with climate indices across China. International Journal of Climatology, 37(1), 468-479.

Zamani, R., Mirabbasi, R., Nazeri, M., Meshram, S.G. and Ahmadi, F. (2018) Spatiotemporal analysis of daily, seasonal and annual precipitation concentration in Jharkhand state, India. Stochastic Environmental Research and Risk Assessment, 32(4), 1085-1097. 

Figures

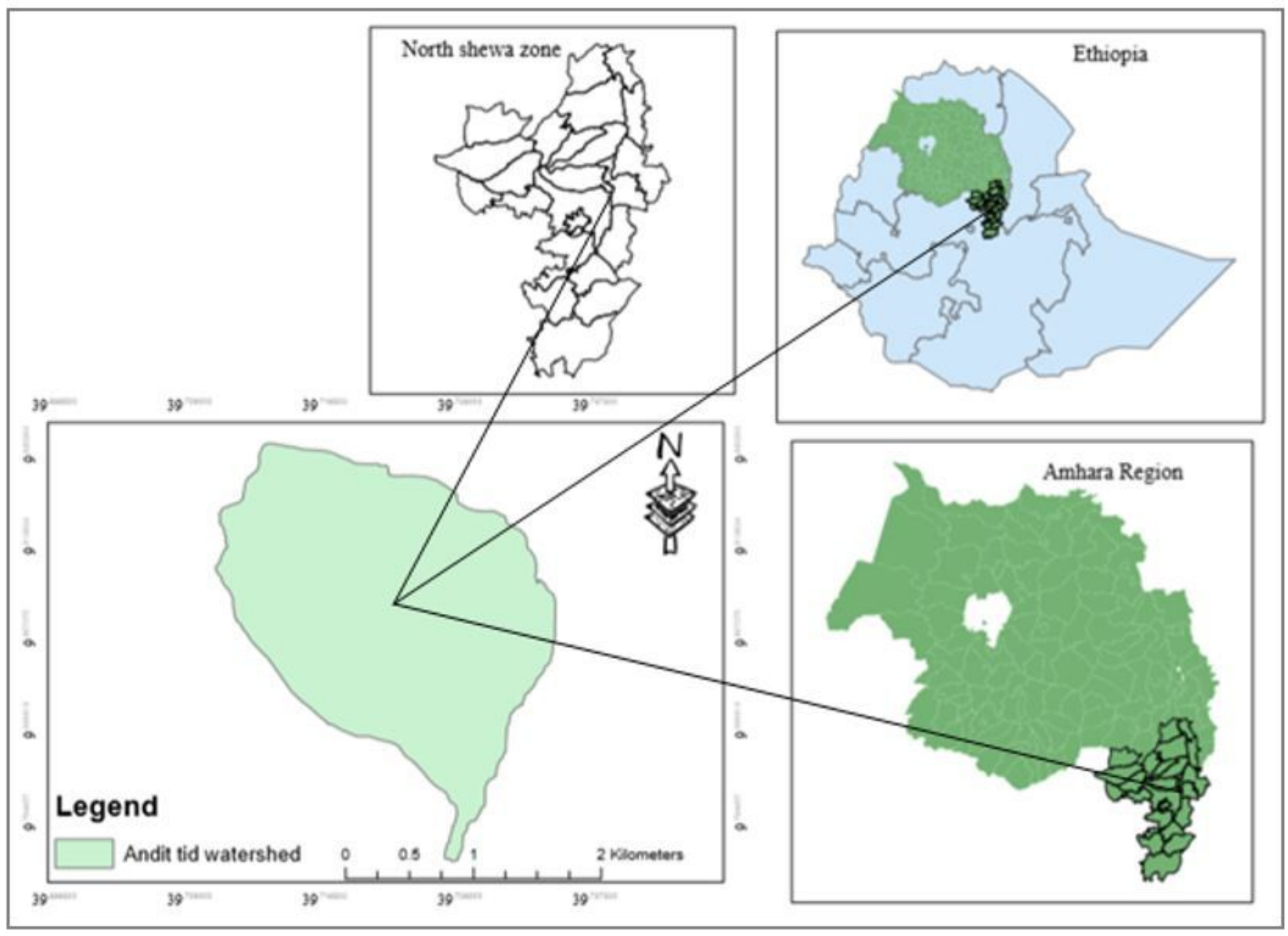

Figure 1

The location map of the study area 


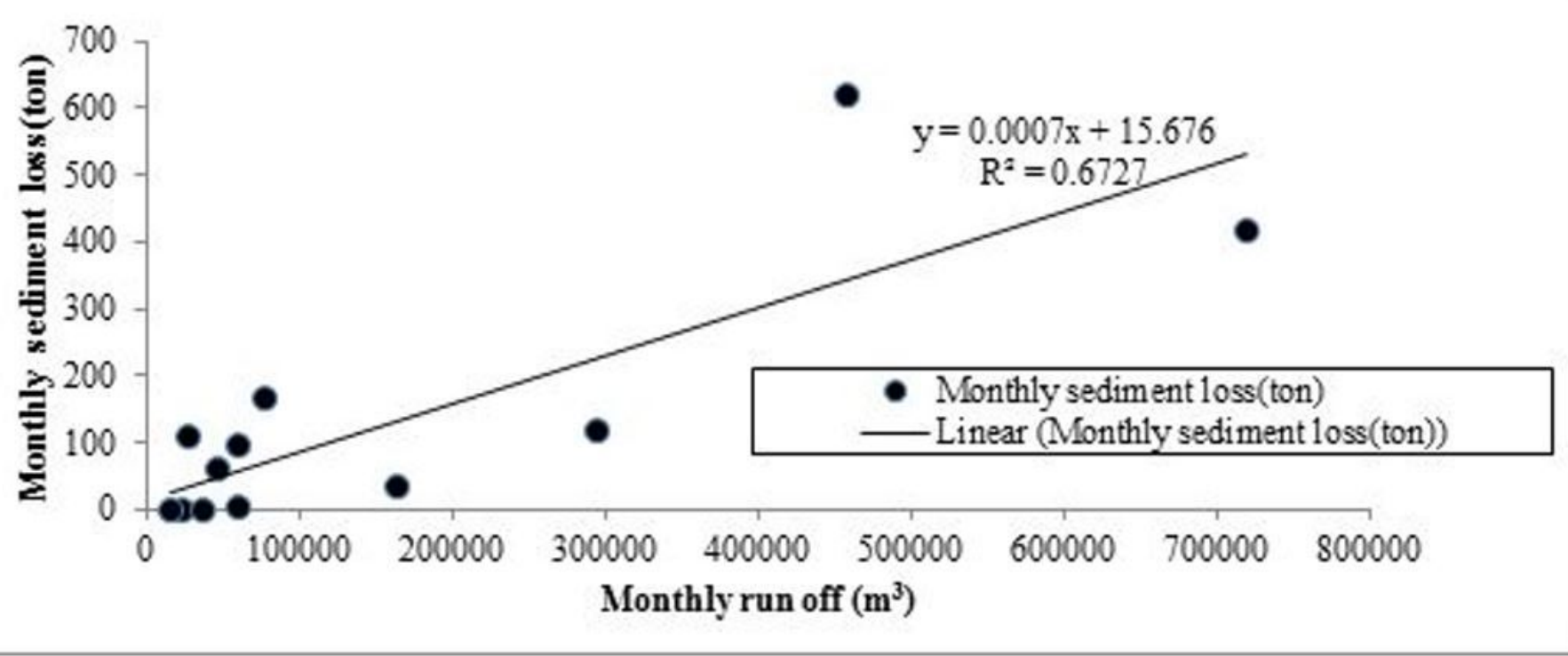

Figure 2

The regression chart of monthly sediment loss (ton) and runoff volume (m3) The relationship between river discharge and sediment loss in Andit Tid watershed is $67.27 \%$. The result indicated that as the river discharge increased by $10 \mathrm{~m} 3$ the sediment loss will increase by $6.7 \mathrm{~kg}$ of sediment. This result confirms that 67 percent of the agent of sediment loss is runoff and the remaining 33 percent is the result of other factors (edaphic, topographic, and land cover).

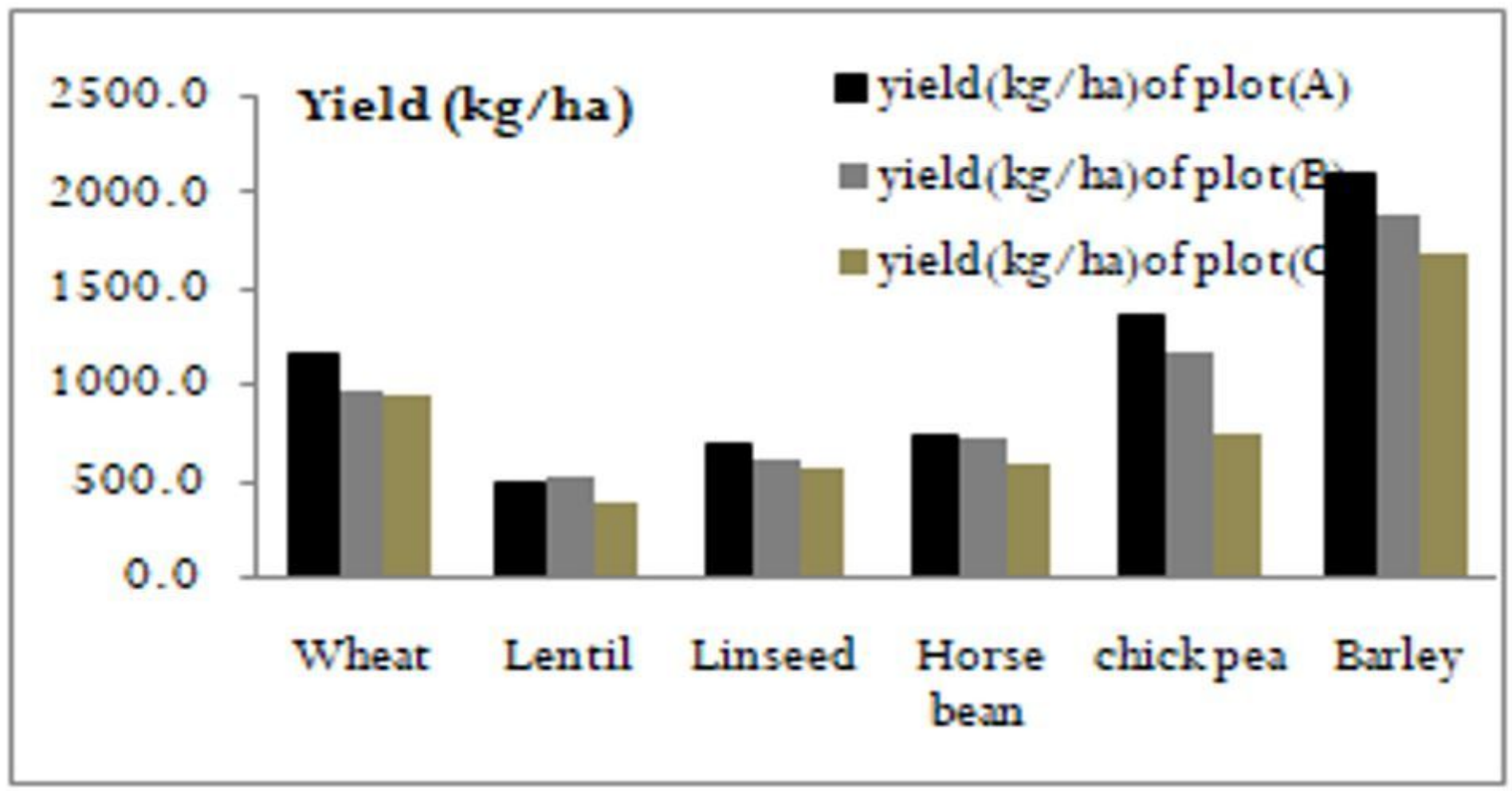

Figure 3 
The long term mean response of major crops yield for different locations of terraces 